\title{
PSEUDOMAQUISES IN SW BULGARIA AS A HABITAT FOR THE GROUND BEETLES (COLEOPTERA: CARABIDAE)
}

\author{
Teodora Teofilova*
}

Institute of Biodiversity and Ecosystem Research (IBER), Bulgarian Academy of Sciences (BAS), 1 Tsar Osvoboditel Blvd., 1000 Sofia, Bulgaria

*Corresponding author. Email: oberon_zoo@abv.bg

\author{
Article history \\ Received: 27 March 2020; \\ accepted 16 April 2020
}

\section{Keywords:}

Carabids; Struma Valley; Pirin Mountains; new data; kermes oak

\begin{abstract}
A lack of sufficient data about ground beetles in maquis and maquis-like habitats in the whole Mediterranean region prompted this study. It brings new data to the knowledge of Carabidae species from Balkan pseudomaquis habitats in Bulgaria and reveals some patterns of species composition from zoogeographic and ecological points of view. Fieldwork was carried out in the period 5 April 2002 - 11 January 2004. A total of 305 specimens from 52 species were found, including two Balkan endemics and one Tertiary relict. These species belong to 23 genera and 12 tribes. Dromius quadrimaculatus (Linnaeus, 1758) and Harpalus fuscicornis Ménétriés, 1832 are new for the Bulgarian Struma Valley. Another 13 species are new for the Pirin Mountains. The richest tribe was Harpalini (21 species), followed by Carabini (6 species), Amarini and Sphodrini (5 species each). The most species-rich genus was Harpalus (13 species). Zoogeographical analysis showed that Euroasiatic and Mediterranean complexes were most prevalent. Xerothermic conditions in the habitats studied were also confirmed by the prevalence of the mesoxerophilous carabids. These habitats occur only locally in Bulgaria and support specific carabid assemblages. Knowledge about their diversity could be a keystone for the conservation of all target species living in these limited areas and encompassed by the adjacent Natura 2000 zones.
\end{abstract}

\section{INTRODUCTION}

The kermes oak (Quercus coccifera Linnaeus, 1753) is the most common species of the Mediterranean maquis, thriving in a wide variety of often contrasting environments, and it has a wide distribution across the Mediterranean Basin (Balaguer et al. 2004; Tsiourlis et al. 2009). In Bulgaria, kermes oak shrubs and forests have a relict origin and form the northern boundary of the typical Mediterranean type of vegetation. They are called Balkan pseudomaquises (EUNIS code: F5.31 Helleno-Balkan pseudomaquis) and are included in the Red Data Book of Bulgaria as Nearly Threatened (Gusev et al. 2015). Pseudomaquises are mixed sclerophyllous evergreen and deciduous shrub thickets of the periphery of the range of Mediterranean sclerophyllous scrublands, with a mixture of Mediterranean and sub-Mediterranean xerophilic bushes and small trees including Quercus coccifera L., Juniperus oxycedrus L., Carpinus orientalis Mill., Ostrya carpinifolia Scop., Pistacia terebinthus L., Buxus sempervirens L., Paliurus spina-christi Mill., Pyrus spinosa Forssk., and Rosa spp. In Bulgaria, these habitats occur in the conditions of Transitional-Mediterranean climate, in the belt of the xerothermic oak forests in the valleys of Struma, Maritsa and Tundzha rivers and along the Black Sea coast (Gusev et al. 2015). The kermes oak was also found in Shavara site in Slavyanka Mountain, also in SW Bulgaria (Langourov et al. 2008).
Habitats encompass $0.5-3.0 \mathrm{~m}$ high xerothermic mixed scrub. These communities represent a transition to the Mediterranean maquis and transitional-continental scrub ("shiblyak" in Bulgarian), where many xerophilic and southern thermophilous species of plants and animals occur. The pseudomaquises are predominately shrublike communities of oaks degraded by timber cutting and grazing in thermophilous deciduous woodlands (Gusev et al. 2015). The main threats are grazing, fires, exploitation of inert materials, and afforestation with alien coniferous species. These habitats need some conservation measures as detailed phytocoenological studies, monitoring and proclamation of protected areas that will encompass representative parts of this habitat type (Gusev et al. 2015). Climate and anthropogenic pressure have been identified to be the most important factors determining the structure and the floristic composition of $Q$. coccifera Mediterranean shrublands in Greece (Tsiourlis et al. 2009).

Sclerophyllous Mediterranean shrub formations are generally poorly known in terms of their Coleoptera faunas (Kaltsas et al. 2012). Ground beetles (Carabidae) and darkling beetles (Tenebrionidae) are two dominant families in the epigean component of mesofauna in Mediterranean-type ecosystems in terms of abundance, diversity and biomass (di Castri and Vitali-di Castri 1981). Carabids are found to be an adequate biodiversity indicator for organic and abandoned olive groves and maquises, which would greatly facilitate conservation 
efforts and related decision-making in the ecosystems of Mediterranean region (Solomou and Sfougaris 2016).

The study region has a very high and peculiar biodiversity. In parallel with the present study, there were established 225 species of spiders (Araneae), of which 17 species were new to the Bulgarian fauna (Lazarov 2005, 2009). During the same study, more than 1430 species of animals were established, of which 17 were endemic, 15 relict, 37 rare, and 73 new species, demonstrating the high conservation significance of the kermes oak communities (Langourov and Simov 2006). The sampling site near Kalimantsi vill. (South Pirin Mountains) falls within the territory of two Natura 2000 zones: SCI under EU Directive 92/43 "Sreden Pirin - Alibotush" (BG0001028) and SPA under EU Directive 79/409 "Melnishki Piramidi“" (BG0002072). The sampling site near Kamenitsa vill. (Struma Valley) also falls within the territory of two Natura 2000 zones: SCI "Kresna - Ilindentsi” (BG0000366) and SPA "Kresna" (BG0002003).

Biodiversity in kermes oak habitats is poorly researched faunistically and ecologically. The selected sampling sites fall within the territories that need further in-depth research accordance with the Bulgarian Biodiversity Strategy and are defined as unique and rare relict Mediterranean habitats (Langourov and Simov 2006).

The aim of the present study was to add new data to the knowledge of Carabidae species in pseudomaquises in Bulgaria and to reveal some patterns of the species composition from zoogeographic and ecological points of view in the specific habitats we studied.

\section{MATERIALS AND METHODS}

Fieldwork was carried out during the period 5 April 2002 - 11 January 2004. Material was collected in two selected pseudomaquis habitats situated at an altitude of 120 up to $510 \mathrm{~m}$ a.s.l. in a region with the Submediterranean climate. The locations of the sampling sites are presented in Figure 1. They were:

1) Pirin: Bulgaria GL09, South Pirin Mountains, N 41⒉ 27.612 , E 2329.448, 450-510 m, SE slope of Sveti Iliya Hill near Kalimantsi vill. (28.4 ha).

2) Struma: Bulgaria FM71, Struma River Valley, near the foot of the Maleshevska Mountains, 170-240 m, $2 \mathrm{~km} \mathrm{~S}$ from Kamenitsa vill. (about $20 \mathrm{ha}$ ).

Ground beetles were collected by colleagues from the Institute of Biodiversity and Ecosystem Research (IBER) and National Museum of Natural History (NMNH) (both under the Bulgarian Academy of Sciences, Sofia): Dr Dragan Chobanov (IBER), Dr Mario Langourov (NMNH), Dr Nikolay Simov (NMNH), Dr Stoyan La- zarov (NMNH), Dr Stoyan Beshkov (NMNH), and Dr Kaloyan Ivanov (then in the former Institute of Zoology, now IBER \& University of Cleveland). Sampling was done via handpicking, tree traps and terrestrial pitfall traps made of plastic beakers, buried at the level of the ground surface and filled with $4 \%$ formaldechyde and a small amount of detergent. It has been established that combined methods of collecting ground beetles are preferable, and not only in Mediterranean regions (Timm et al. 2008). The study lines served by thirty pitfall traps (15 soil traps and 15 tree traps with a mouth diameter of $9 \mathrm{~cm}$ ) were placed in a line about 10 meters apart from each other at each study point and traps were emptied monthly. Captured animals were stored in the Carabidae collection of the author in the Institute of Biodiversity and Ecosystem Research.

According to their zoogeographical provenance, the ground beetles were separated into zoogeographical categories and complexes according to Kryzhanovskij (1983) and Kodzhabashev and Penev (2006), with some changes made by the author of the present study.

According to their ecological requirements in terms of humidity, the established carabid species were divided into 6 categories: hygrophilous, mesohygrophilous, mesophilous, mesoxerophilous, xerophilous, and eurybionts.

Categorization of the species in respect of their life forms followed the classification of Sharova (1981).

\section{RESULTS}

During the fieldwork, an aggregate of 305 specimens was captured. They belonged to 52 species, 23 genera and 12 tribes of ground beetles. Twenty genera, 37 species and 138 specimens were found in the first sampling site (Pirin Mountains), and 14 genera, 29 species and 167 specimens in the second (Struma Valley). Twentyfour species were caught exclusively at the first site, 16 species were caught only in the second site, and 13 species were common for both sampling sites. A complete checklist of established species with the full species name, author and year of description, zoogeographic category, life form, and ecological group in relation to humidity is given in Table 1.

The richest tribe was Harpalini (21 species), followed by Carabini (6 species), Amarini and Sphodrini (5 species each), and Lebiini (4 species). Bembidiini, Callistini, Pterostichini, and Trechini were represented by 2 species each. Brachinini, Cicindelini, and Notiophilini had only one species each. The most species-rich genus was Harpalus (13 species). Genera Ophonus and Carabus were represented by 4 species each, and genera $A c i-$ nopus, Amara, and Calathus had 3 species each. The 


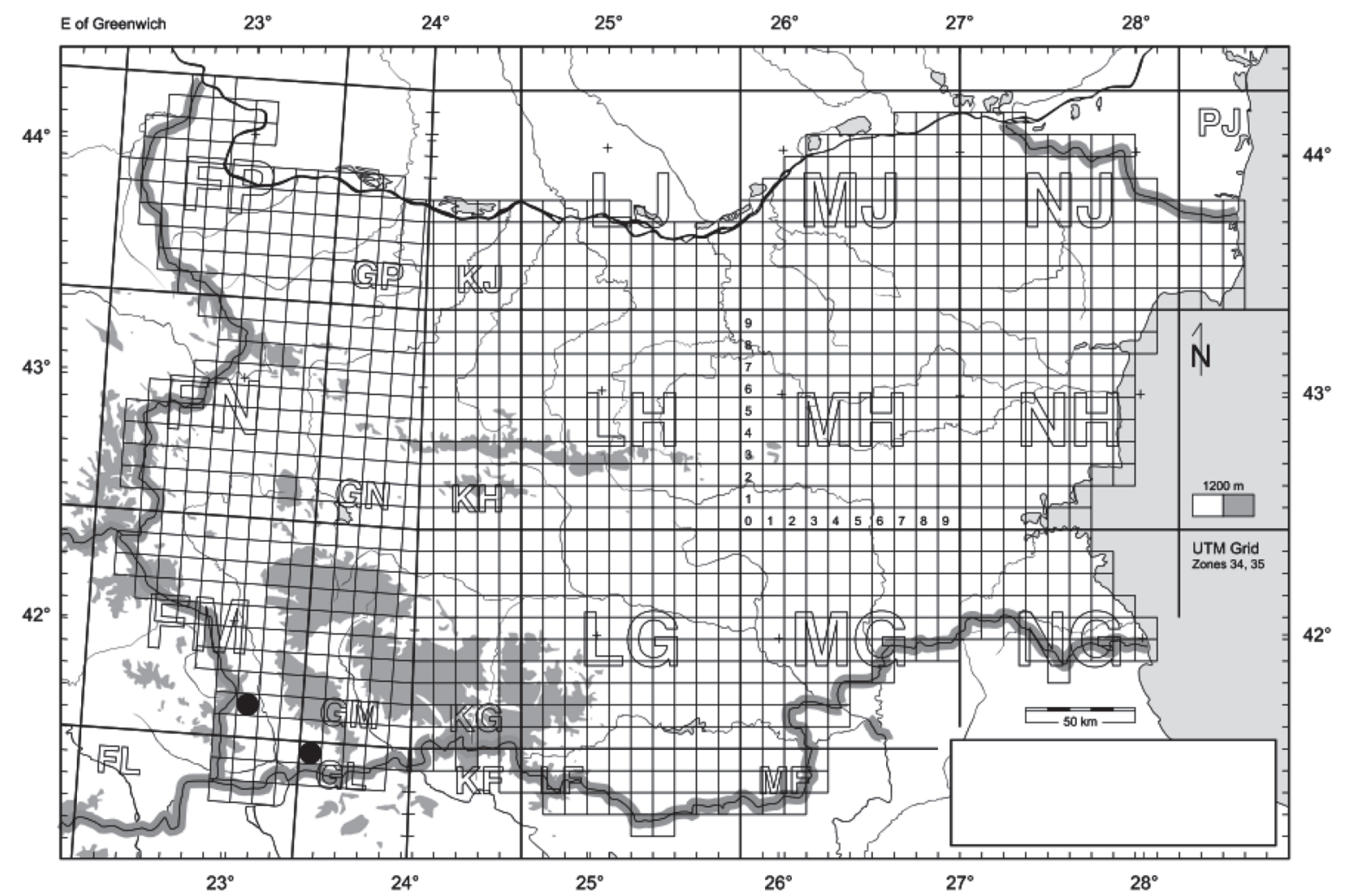

Figure 1. Pseudomaquis habitats in SW Bulgaria, where the study was conducted: Kamenitsa vill., FM 71 (Struma Valley) and Kalimantsi, GL 09 (Pirin Mountains). Source: Lazarov 2005.

most abundant species were Carabus morio, Calathus cinctus, Zabrus incrassatus, Calosoma inquisitor, Carabus coriaceus, and Acinopus picipes. The dominance structure of the two sampling sites is given in Table 2 , and it shows some differences among carabid coenoses in the two habitats.

Dromius quadrimaculatus and Harpalus fuscicornis are new for the Bulgarian Struma Valley. Another 13 species are new for the Pirin Mountains: Calathus distinguendus, Calathus cinctus, Calosoma inquisitor, Chlaenius cruralis, Chl. decipiens, Dixus obscurus, Harpalus hospes, H. sulphuripes, H. signaticornis, Myas chalybaeus, Notiophilus rufipes, Ophonus sabulicola, and Sinechostictus effluviorum.

New high altitude boundaries were established for the distribution of two species now found in Pirin Mountains at 450-510 m.: Calathus cinctus (so far known only from below $340 \mathrm{~m}$ a.s.1.) and Chlaenius cruralis (so far known only from about $300 \mathrm{~m}$ a.s.1.).

In this study, we found one Tertiary relict (Myas chalybaeus) and two Balkan endemics (Harpalus triseriatus and Zabrus incrassatus). Carabus intricatus is included in the IUCN Red List as Near Threatened. Carabus intricatus and Calosoma sycophanta are included in the Annexes of CORINE and ESC Red List.

Some rare and stenotopic species also occurred in the studied region: Calosoma sycophanta (mesophilous forests), Chlaenius cruralis (rarely, in xerothermic open habitats), Dromius quadrimaculatus (mesophilous forests), Harpalus triseriatus (rarely, in mesoxerophilous open habitats), and Sinechostictus effluviorum (banks and wet habitats near water).

The results from the zoogeographical analysis showed that in the first site (Pirin Mountains) the EuropeanAsiatic complex had the same ratios as the Mediterranean (sensu lato) complex (10 species each) (Figure 2). It includes species the ranges of which lie between the Eurosiberian and Mediterranean zones. Mediterranean species are distributed in the so-called region of the "Ancient Mediterraneum" (Popov 1927; Kryzhanovskij 1965, 1983). Following in number of species was the Northern Holarctic and European-Siberian complex (8 species). This complex includes species distributed mainly in the northern regions of the Holarctic, mostly in Europe and Siberia. The European complex consisted of 6 species, and Endemic complex of 3 species. The European complex includes mostly forest dwelling species connected to the middle and southern part of Europe.

The European-Asiatic complex prevailed in the second site (Struma Valley) too (11 species). It was followed by the Mediterranean ( 7 species) and the Northern Holarctic and European-Siberian complex (6 species). The least represented were the European ( 3 species) and the Endemic complex (2 species) (Figure 2). 
Table 1. List of the ground beetles found in pseudomaquis habitats in SW Bulgaria in 2002-2003. * - new species for the Pirin Mountains; ** - new species for the Struma Valley. ZC - zoogeographic category (explanations are given in Table 2 in the Results section); LF - life form (explanations are given in the Methods section); HP - humidity preference (H - hygrophilous, $\mathrm{MH}$ - mesohygrophilous, $\mathrm{M}$ - mesophilous, $\mathrm{MX}$ - mesoxerophilous, $\mathrm{X}$ - xerophilous, $\mathrm{E}$ - eurybiont); $q$ - female, $\widehat{\partial}-$ male; (d/D). $100 \%$ - degree of dominance.

\begin{tabular}{|c|c|c|c|c|c|c|c|c|c|c|c|c|c|}
\hline \multirow[b]{2}{*}{ No } & \multirow[b]{2}{*}{ Species } & \multirow[b]{2}{*}{$\mathrm{ZC}$} & \multirow[b]{2}{*}{ LF } & \multirow[b]{2}{*}{$\mathrm{HP}$} & \multicolumn{4}{|c|}{ GL09 Pirin } & \multicolumn{4}{|c|}{ FM71 Struma } & \multirow{2}{*}{$\begin{array}{c}\text { Total } \\
\text { No of } \\
\text { specimens }\end{array}$} \\
\hline & & & & & q & $\sigma^{\lambda}$ & total & $\begin{array}{l}(\mathrm{d} / \mathrm{D}) . \\
100 \%\end{array}$ & q & $\hat{\sigma}$ & total & $\begin{array}{l}(\mathrm{d} / \mathrm{D}) \\
100 \%\end{array}$ & \\
\hline 1. & Acinopus (Acinopus) picipes (Olivier, 1795) & NMED & 2.3 .2 & MX & & & & & 6 & 10 & 16 & 9.6 & 16 \\
\hline 2. & A. (Oedematicus) megacephalus (P. Rossi, 1794) & NMED & 2.3.2. & MX & & & & & & 2 & 2 & 1.2 & 2 \\
\hline 3. & A. (Osimus) ammophilus Dejean, 1829 & CE-PAS & 2.3.2. & $\mathrm{X}$ & & 2 & 2 & 1.45 & 4 & 2 & 6 & 3.6 & 8 \\
\hline 4. & Amara (Amara) aenea (De Geer, 1774) & OLA & 2.3.1. & MX & 1 & & 1 & 0.7 & & 1 & 1 & 0.6 & 2 \\
\hline 5. & A. (Amara) anthobia A. Villa et G. B. Villa, 1833 & E-PAS & 2.1.1. & MX & & & & & 2 & & 2 & 1.2 & 2 \\
\hline 6. & A. (Amara) lucida (Duftschmid, 1812) & E-PA-M & 2.3.1. & MH & & & & & & 1 & 1 & 0.6 & 1 \\
\hline 7. & Bembidion (Peryphanes) dalmatinum Dejean, 1831 & CE-PAS & $1.3(1) .1$ & $\mathrm{H}$ & & 1 & 1 & 0.7 & & & & & 1 \\
\hline 8. & Brachinus (Brachynidius) explodens Duftschmid, 1812 & E-CAS & $1.3(1) \cdot 3$ & MX & & & & & & 1 & 1 & 0.6 & 1 \\
\hline 9. & ${ }^{*}$ Calathus (Calathus) distinguendus Chaudoir, 1846 & B-PAS & $1.3(1) \cdot 2$ & MX & 1 & & 1 & 0.7 & & & & & 1 \\
\hline 10. & C. (Calathus) fuscipes (Goeze, 1777) & PAL & $1.3(1) \cdot 2$ & $\mathrm{E}$ & & & & & & 1 & 1 & 0.6 & 1 \\
\hline 11. & ${ }^{*}$ C. (Neocalathus) cinctus Motschulsky, 1850 & E-PAS & $1.3(1) \cdot 2$ & MX & 23 & 9 & 32 & 23.2 & & & & & 32 \\
\hline 12. & *Calosoma (Calosoma) inquisitor (Linnaeus, 1758) & PAL & $1.2 .2(1)$ & MX & 3 & 22 & 25 & 18.1 & 4 & 2 & 6 & 3.6 & 31 \\
\hline 13. & C. (Calosoma) sycophanta (Linnaeus, 1758$)$ & PAL & 1.2.2(1) & M & & 1 & 1 & 0.7 & & & & & 1 \\
\hline 14. & Carabus (Chaetocarabus) intricatus Linnaeus, 1760 & EUR & 1.2 .2 & $\mathrm{MH}$ & 1 & & 1 & 0.7 & & & & & 1 \\
\hline 15. & C. (Pachystus) morio Mannerheim, 1830 & B-PAS & 1.2.2. & MX & 2 & 2 & 4 & 2.9 & 28 & 21 & 49 & 29.3 & 53 \\
\hline 16. & C. (Procrustes) coriaceus Linnaeus, 1758 & E-PAS & 1.2 .2 & $\mathrm{E}$ & 7 & 5 & 12 & 8.7 & 5 & 6 & 11 & 6.6 & 23 \\
\hline 17. & C. (Tomocarabus) convexus Fabricius, 1775 & E-PAS & 1.2.2. & MX & & & & & 2 & 1 & 3 & 1.8 & 3 \\
\hline 18. & $\begin{array}{l}\text { *Chlaenius (Dinodes) cruralis Fischer von Waldheim, } \\
1829\end{array}$ & B-CAS & $1.3(1) .1$ & $\mathrm{X}$ & 3 & & 3 & 2.2 & & & & & 3 \\
\hline 19. & *Chl. (Dinodes) decipiens (L. Dufour, 1820) & E-PA-M & $1.3(1) .1$ & MX & 1 & & 1 & 0.7 & & & & & 1 \\
\hline 20. & Cicindela (Cicindela) campestris Linnaeus, 1758 & PAL & 1.2 .4 & MX & & 2 & 2 & 1.45 & & & & & 2 \\
\hline 21. & Cymindis (Cymindis) axillaris (Fabricius, 1794) & E-PA-M & $1.3(1) \cdot 3$ & MX & 1 & & 1 & 0.7 & & & & & 1 \\
\hline 22. & *Dixus obscurus (Dejean, 1825$)$ & NM-CAS & 2.3.3. & $\mathrm{X}$ & 1 & 1 & 2 & 1.45 & 2 & 2 & 4 & 2.4 & 6 \\
\hline 23. & **Dromius (Dromius) quadrimaculatus (Linnaeus, 1758) & EUR & $1.3(1) .5$ & $\mathrm{M}$ & & & & & 1 & 1 & 2 & 1.2 & 2 \\
\hline 24. & Harpalus (Harpalus) attenuatus Stephens, 1828 & E-PA-M & 2.3 .1 & MX & 2 & 1 & 3 & 2.2 & & 1 & 1 & 0.6 & 4 \\
\hline 25. & H. (Harpalus) dimidiatus (P. Rossi, 1790) & E-PAS & 2.3.1. & MX & & & & & 7 & 4 & 11 & 6.6 & 11 \\
\hline 26. & H. (Harpalus) flavicornis Dejean, 1829 & CE-PAS & 2.3.1. & MX & & & & & 2 & & 2 & 1.2 & 2 \\
\hline 27. & **H. (Harpalus) fuscicornis Ménétriés, 1832 & WPAL & 2.3.1. & MX & & & & & & 1 & 1 & 0.6 & 1 \\
\hline 28. & H. (Harpalus) honestus (Duftschmid, 1812) & E-PAS & 2.3.1. & MX & 1 & 1 & 2 & 1.45 & 1 & 1 & 2 & 1.2 & 4 \\
\hline 29. & *H. (Harpalus) hospes Sturm, 1818 & CE-PAS & 2.3 .1 & $\mathrm{X}$ & & 1 & 1 & 0.7 & & & & & 1 \\
\hline 30. & H. (Harpalus) pumilus Sturm, 1818 & E-CAS & 2.3.1. & MX & 1 & & 1 & 0.7 & & & & & 1 \\
\hline 31. & H. (Harpalus) rubripes (Duftschmid, 1812) & OLA & 2.3.1. & MX & & 1 & 1 & 0.7 & 1 & & 1 & 0.6 & 2 \\
\hline 32. & H. (Harpalus) serripes (Quensel, 1806) & WPAL & 2.3.1. & MX & 5 & 2 & 7 & 5.1 & 1 & 2 & 3 & 1.8 & 10 \\
\hline 33. & *H. (Harpalus) sulphuripes Germar, 1823 & CEE-PA & 2.3.1. & M & 1 & 2 & 3 & 2.2 & & & & & 3 \\
\hline 34. & H. (Harpalus) tardus (Panzer, 1796) & E-CAS & 2.3.1. & $\mathrm{E}$ & 2 & 3 & 5 & 3.6 & 1 & 3 & 4 & 2.4 & 9 \\
\hline 35. & H. (Harpalus) triseriatus A. Fleischer, 1897 & BAL & 2.3.1. & MX & & 1 & 1 & 0.7 & 1 & & 1 & 0.6 & 2 \\
\hline 36. & *H. (Semiophonus) signaticornis (Duftschmid, 1812) & PAL & 2.2 .1 & MX & 1 & & 1 & 0.7 & & & & & 1 \\
\hline 37. & $\begin{array}{l}\text { Laemostenus (Pristonychus) cimmerius (Fischer von } \\
\text { Waldheim, 1823) }\end{array}$ & P-SMED & $1.3(1) \cdot 6$ & M & & & & & 2 & 2 & 4 & 2.4 & 4 \\
\hline 38. & L. (Pristonychus) terricola (Herbst, 1784) & WPAL & $1.3(1) .6$ & $\mathrm{M}$ & 1 & & 1 & 0.7 & & & & & 1 \\
\hline 39. & Microlestes fissuralis (Reitter, 1901) & E-CAS & $1.3(1) \cdot 3$ & $\mathrm{M}$ & 1 & & 1 & 0.7 & 1 & & 1 & 0.6 & 1 \\
\hline 40. & *Myas (Myas) chalybaeus (Palliardi, 1825) & BAL-K & $1.3(2) .1$ & $\mathrm{M}$ & & 1 & 1 & 0.7 & & & & & 1 \\
\hline 41. & *Notiophilus rufipes Curtis, 1829 & E-PAS & $1.3(1) .1$ & M & 1 & 1 & 2 & 1.45 & & & & & 2 \\
\hline 42. & Ophonus (Hesperophonus) cribricollis (Dejean, 1829) & E-CAS & 2.2 .1 & MX & & & & & 3 & 2 & 5 & 3 & 5 \\
\hline 43. & Ophonus (Hesperophonus) similis (Dejean, 1829) & P-SMED & 2.2.1. & M & & 1 & 1 & 0.7 & & & & & 1 \\
\hline 44. & O. (Metophonus) laticollis Mannerheim, 1825 & E-CAS & 2.2 .1 & MX & 1 & & 1 & 0.7 & & & & & 1 \\
\hline 45. & *O. (Ophonus) sabulicola (Panzer, 1796) & E-PAS & 2.2 .1 & MX & & 1 & 1 & 0.7 & & & & & 1 \\
\hline 46. & Pterostichus (Platysma) niger (Schaller, 1783) & E-AS & $1.3(2) .1$ & MH & & & & & & 1 & 1 & 0.6 & 1 \\
\hline 47. & *Sinechostictus (Sinechostictus) effluviorum Peyron, 1858 & CEE-PA & $1.3(1) \cdot 2$ & $\mathrm{H}$ & & 1 & 1 & 0.7 & & & & & 1 \\
\hline 48. & Syntomus pallipes (Dejean, 1825) & E-CA-M & $1.3(1) \cdot 3$ & MX & 1 & & 1 & 0.7 & & & & & 1 \\
\hline 49. & Trechus (Trechus) quadristriatus (Schrank, 1781) & E-CA-M & $1.3(1) \cdot 2$ & $\mathrm{E}$ & 3 & 1 & 4 & 2.9 & & & & & 4 \\
\hline 50. & Tr. (Trechus) subnotatus Dejean, 1831 & NMED & $1.3(1) \cdot 2$ & M & & 1 & 1 & 0.7 & & & & & 1 \\
\hline 51. & Zabrus (Pelor) incrassatus Germar, 1814 & BAL & 2.3 .2 & MX & 3 & 6 & 9 & 6.5 & 7 & 16 & 23 & 13.8 & 32 \\
\hline \multirow[t]{2}{*}{52.} & Z. (Zabrus) tenebrioides (Goeze, 1777) & E-CAS & 2.3.2. & MX & & & & & 2 & & 2 & 1.2 & 2 \\
\hline & \multicolumn{4}{|l|}{ Total: } & 68 & 70 & 138 & & 83 & 84 & 167 & & 305 \\
\hline
\end{tabular}


Table 2. Dominance structure of the ground beetles found in both sampling sites.

\begin{tabular}{|c|c|c|c|c|}
\hline \multirow{2}{*}{$(\mathrm{d} / \mathrm{D}) .100 \%$} & \multicolumn{2}{|l|}{ Pirin (Kalimantsi vill.) } & \multicolumn{2}{|l|}{ Struma Valley (Kamenitsa vill.) } \\
\hline & Species & No & Species & No \\
\hline $\begin{array}{l}\text { Eudominant } \\
>10 \%\end{array}$ & Calathus cinctus, Calosoma inquisitor & 2 & Carabus morio, Zabrus incrassatus & 2 \\
\hline $\begin{array}{l}\text { Dominant } \\
5-10 \%\end{array}$ & $\begin{array}{l}\text { Carabus coriaceus, Harpalus serripes, } \\
\text { Zabrus incrassatus }\end{array}$ & 3 & $\begin{array}{l}\text { Acinopus picipes, Carabus coriaceus, Harpalus } \\
\text { dimidiatus }\end{array}$ & 3 \\
\hline $\begin{array}{l}\text { Subdominant } \\
3-5 \%\end{array}$ & Harpalus tardus & 1 & $\begin{array}{l}\text { Acinopus ammophilus, Calosoma inquisitor, } \\
\text { Ophonus cribricollis }\end{array}$ & 3 \\
\hline $\begin{array}{l}\text { Recedent } \\
1-3 \%\end{array}$ & $\begin{array}{l}\text { Acinopus ammophilus, Carabus morio, } \\
\text { Chlaenius cruralis, Cicindela campestris, } \\
\text { Dixus obscurus, Harpalus attenuatus, H. } \\
\text { honestus, H. sulphuripes, Notiophilus rufipes, } \\
\text { Trechus quadristriatus }\end{array}$ & 10 & $\begin{array}{l}\text { Acinopus megacephalus, Amara anthobia, } \\
\text { Carabus convexus, Dixus obscurus, Dromius } \\
\text { quadrimaculatus, Harpalus flavicornis, } \text { H. } \\
\text { honestus, H. serripes, H. tardus, Laemostenus } \\
\text { cimmerius, Zabrus tenebrioides }\end{array}$ & 11 \\
\hline $\begin{array}{l}\text { Subrecedent } \\
<1 \%\end{array}$ & All the rest & 21 & All the rest & 10 \\
\hline
\end{tabular}
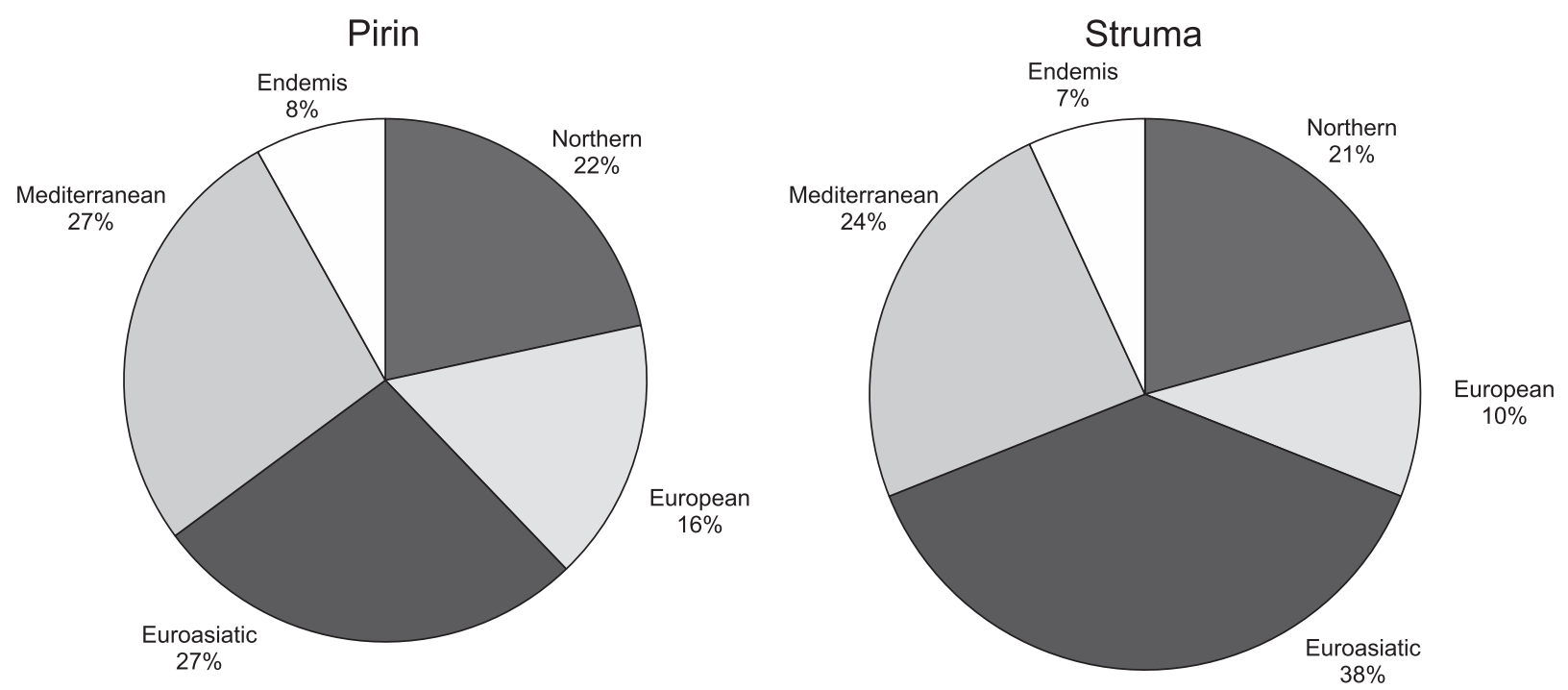

Figure 2. Distribution of the carabid species from two localities (left: Pirin Mountains, near Kalimantsi vill.; right: Struma Valey, near Kamenitsa vill.) among the zoogeographical complexes.

Similarly to the findings about the zoogeography of the ground beetles from the Eastern Rhodope Mountains (Teofilova and Kodzhabashev 2020), in this study the greatest number of species belonged to the EuropeanCentral Asian and European-Neareastern categories, with the Palaearctic complex species being also abundant in the first sampling site (Pirin Mountains) (Table 3).

The ground beetles established during the study belonged to two classes of life forms proposed by Sharova (1981). In the first site (Pirin), class Zoophagous slightly prevailed (20 species, 54\%) over the class Mixophyitophagous (17 species, $46 \%$ ). In the second site (Struma), class Mixophyitophagous prevailed with 19 species $(65.5 \%)$ over the class Zoophagous with 10 species (34.5\%) (Table 4, Figure 3).

A total of 14 life form groups of ground beetles were established -9 zoophagous and 5 mixophytophagous, with different proportions between the two sampling sites. In both sites, the largest proportion of species

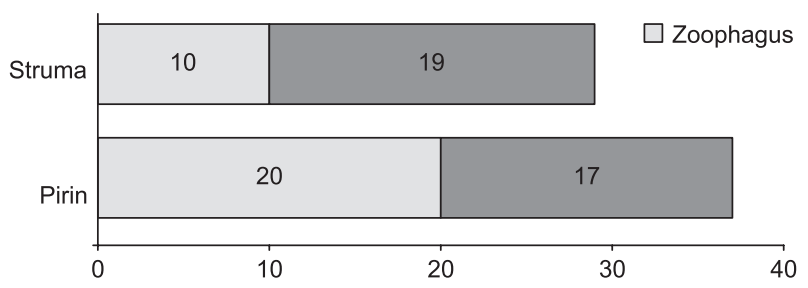

Figure 3. Proportions (number of species) of the classes of life forms in the carabid coenoses.

belonged to the specialized phytophagous harpaloid geohortobionts from class Mixophytophagous. Harpaloid geohortobionts accounted for $27 \%$ (10 species) of all species established in the first site (Pirin) and 38\% (11 species) in the second site (Struma) (Table 4).

Crevice-dwelling litter stratobionts (Calathus, Sinechostictus, and Trechus spp.) and crevice-dwelling surface \& litter stratobionts (Bembidion, Chlaenius, and Notiophilus spp.) were the most numerous zoophagous groups in Pirin - respectively, 5 (13\%) and 4 (11\%) spe- 
Table 3. Zoogeographical categories of the ground beetles from pseudomaquises in SW Bulgaria (on species level). ZC zoogeographical complex: I - Northern Holarctic and Euro-Siberian, II - European, III - Euroasiatic, IV - Mediterranean, $\mathrm{V}-$ Endemic.

\begin{tabular}{|c|c|c|c|c|c|c|c|c|}
\hline \multirow{2}{*}{$\mathrm{ZC}$} & \multirow{2}{*}{ Code } & \multirow{2}{*}{ Zoogeographical category } & \multicolumn{2}{|l|}{ Pirin } & \multicolumn{2}{|l|}{ Struma } & \multicolumn{2}{|l|}{ Total } \\
\hline & & & No of species & $\%$ & No of species & $\%$ & No of species & $\%$ \\
\hline \multirow{3}{*}{ I } & OLA & Holarctic & 2 & 5 & 2 & 7 & 2 & 4 \\
\hline & PAL & Palaearctic & 4 & 11 & 2 & 7 & 5 & 10 \\
\hline & WPAL & Western Palaearctic & 2 & 5 & 2 & 7 & 3 & 6 \\
\hline \multirow{3}{*}{ II } & EUR & European & 1 & 3 & 1 & 3 & 2 & 4 \\
\hline & CE-PAS & Central European and Neareastern & 3 & 8 & 2 & 7 & 4 & 8 \\
\hline & CEE-PA & Central and Eastern European and Neareastern & 2 & 5 & - & - & 2 & 4 \\
\hline \multirow{4}{*}{ III } & E-AS & Euroasiatic steppe and forest-steppe & - & - & 1 & 3 & 1 & 2 \\
\hline & E-CAS & European and Central Asian & 4 & 11 & 5 & 17 & 7 & 13 \\
\hline & E-PAS & European-Neareastern & 5 & 14 & 5 & 17 & 8 & 15 \\
\hline & B-CAS & Balkan and Central Asian & 1 & 3 & - & - & 1 & 2 \\
\hline \multirow{6}{*}{ IV } & E-CA-M & European-Central Asian-Mediterranean & 2 & 5 & - & - & 2 & 4 \\
\hline & E-PA-M & European-Neareastern-Mediterranean & 3 & 8 & 2 & 7 & 4 & 8 \\
\hline & NM-CAS & Northmediterranean-Central Asian & 1 & 3 & 1 & 3 & 1 & 2 \\
\hline & NMED & Northmediterranean & 1 & 3 & 2 & 7 & 3 & 6 \\
\hline & P-SMED & Pontic-Submediterranean & 1 & 3 & 1 & 3 & 2 & 4 \\
\hline & B-PAS & Balkan-Neareastern & 2 & 5 & 1 & 3 & 2 & 4 \\
\hline \multirow{2}{*}{ V } & BAL-K & Balkan subendemic (+ Balkan-Carpathian) & 1 & 3 & - & - & 1 & 2 \\
\hline & BAL & Balkan endemic & 2 & 5 & 2 & 7 & 2 & 4 \\
\hline \multicolumn{3}{|c|}{ Total: } & 37 & & 29 & & 52 & \\
\hline
\end{tabular}

Table 4. Life forms of the ground beetles from the pseudomaquises. The first digit in the index shows the class of life form, the second shows the subclass, and the third indicates the life form group. The number in brackets after the subclass shows the series, if any.

\begin{tabular}{|c|c|c|c|c|c|c|c|}
\hline \multirow{2}{*}{\multicolumn{2}{|c|}{ Life forms }} & \multicolumn{2}{|l|}{ Pirin } & \multicolumn{2}{|c|}{ Struma } & \multicolumn{2}{|l|}{ Total } \\
\hline & & No of species & $\%$ & No of species & $\%$ & No of species & $\%$ \\
\hline \multicolumn{8}{|c|}{ Class: Zoophagous } \\
\hline \multicolumn{8}{|c|}{ Life form subclass: 1.2 - Epigeobios } \\
\hline 1.2.2. & Large walking epigeobionts & 3 & 8.1 & 3 & 10.3 & 4 & 7.7 \\
\hline 1.2.2(1) & Large walking dendroepigeobionts & 2 & 5.4 & 1 & 3.4 & 2 & 3.8 \\
\hline 1.2 .4 & Flying epigeobionts & 1 & 2.7 & - & - & 1 & 1.9 \\
\hline \multicolumn{8}{|c|}{ Life form subclass: 1.3 - Stratobios } \\
\hline \multicolumn{8}{|c|}{ Series: $1.3(1)$ - crevice-dwelling stratobionts } \\
\hline $1.3(1) .1$ & Surface \& litter-dwelling & 4 & 10.8 & - & - & 4 & 7.7 \\
\hline $1.3(1) .2$ & Litter-dwelling & 5 & 13.5 & 1 & 3.4 & 6 & 11.5 \\
\hline $1.3(1) \cdot 3$ & Litter \& crevice-dwelling & 3 & 8.1 & 2 & 6.9 & 4 & 7.7 \\
\hline $1.3(1) .5$ & Litter \& bark-dwelling & - & - & 1 & 3.4 & 1 & 1.9 \\
\hline $1.3(1) .6$ & Bothrobionts & 1 & 2.7 & 1 & 3.4 & 2 & 3.8 \\
\hline \multicolumn{8}{|c|}{ Series: 1.3(2) - digging stratobionts } \\
\hline $1.3(2) .1$ & Litter \& soil-dwelling & 1 & 2.7 & 1 & 3.4 & 2 & 3.8 \\
\hline \multicolumn{2}{|c|}{ Zoophagous Total: } & 20 & 54.0 & 10 & 34.5 & 26 & 50.0 \\
\hline \multicolumn{8}{|c|}{ Class: Mixophytophagous } \\
\hline \multicolumn{8}{|c|}{ Life form subclass: 2.1 - Stratobios } \\
\hline 2.1.1. & Crevice-dwelling stratobionts & - & - & 1 & 3.4 & 1 & 1.9 \\
\hline \multicolumn{8}{|c|}{ Life form subclass: 2.2 -Stratohortobios } \\
\hline 2.2 .1 & Stratohortobionts & 4 & 10.8 & 1 & 3.4 & 5 & 9.6 \\
\hline \multicolumn{8}{|c|}{ Life form subclass: 2.3 - Geohortobios } \\
\hline 2.3 .1 & Harpaloid geohortobionts & 10 & 27.0 & 11 & 37.9 & 14 & 26.9 \\
\hline 2.3.2. & Zabroid geohortobionts & 2 & 5.4 & 5 & 17.2 & 5 & 9.6 \\
\hline 2.3.3. & Dytomeoid geohortobionts & 1 & 2.7 & 1 & 3.4 & 1 & 1.9 \\
\hline \multicolumn{2}{|c|}{ Mixophytophagous Total: } & 17 & 46.0 & 19 & 65.5 & 26 & $\mathbf{5 0 . 0}$ \\
\hline
\end{tabular}



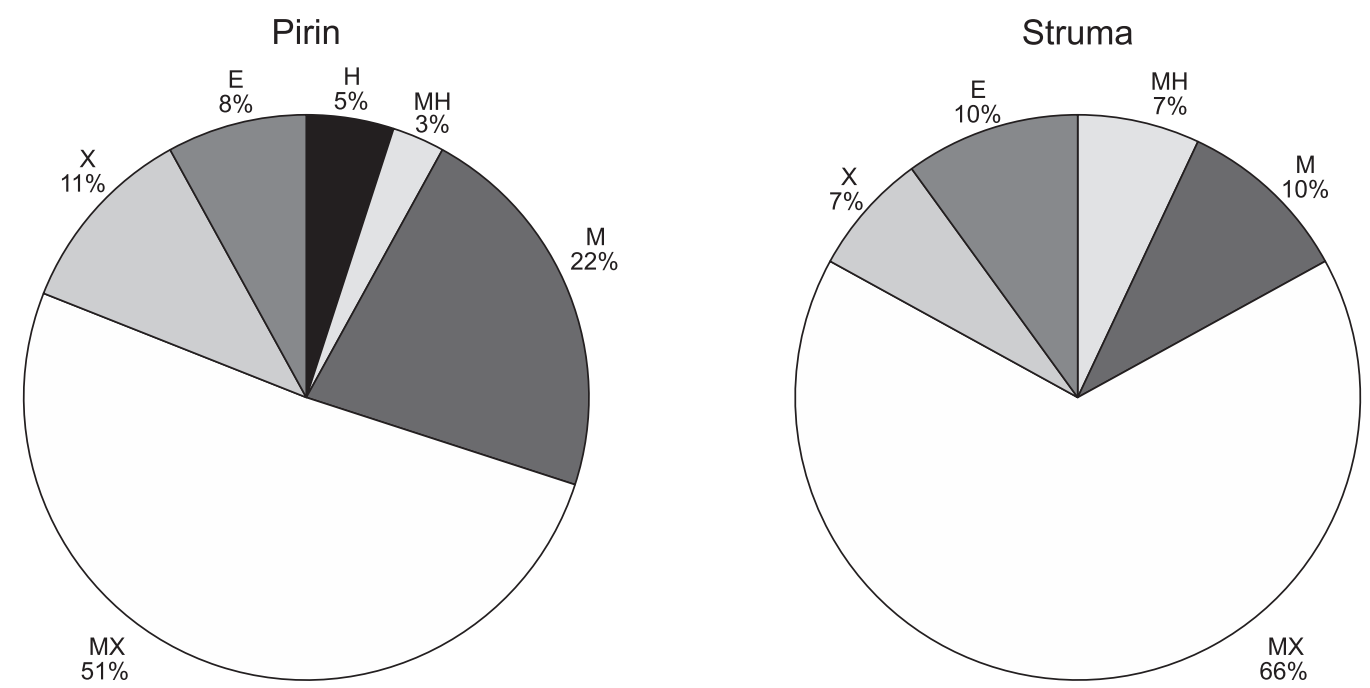

Figure 4. Humidity preferences (number of species) of the carabids ( $\mathrm{H}$ - hygrophilous, $\mathrm{MH}$ - mesohygrophilous; $\mathrm{M}-$ mesophilous, MX - mesoxerophilous, $\mathrm{X}$ - xerophilous, E - eurybiont).

cies, and large walking epigeobionts (Carabus spp.) and litter \& crevice-dwelling stratobionts (Brachinus and Microlestes) predominated in Struma - respectively, $3(10 \%)$ and $2(7 \%)$ species.

Analysis of the humidity preferences of the ground beetles confirmed the xerothermic conditions in the study habitats and showed the prevalence of mesoxerophilous carabids (29 species, $56 \%$ of all established species). Mesoxerophilous ground beetles predominated in both sampling sites, with 19 species $(51 \%)$ in Pirin and 19 species (66\%) in Struma (Figure 4). Mesophilous species were more abundant in Pirin ( 8 species, 22\%) than in Struma (3 species, 10\%), probably resulting from the influence of the mountain climate. The least represented were hygrophilous ( 2 species $(5 \%)$ in Pirin and none in Struma) and mesohygrophilous species ( 1 species (3\%) in Pirin and 2 species (7\%) in Struma). In contrast to the small share of the eurybionts (3\%) found in the Eastern Rhodope Mountains (Teofilova and Kodzhabashev 2020), they accounted for $8 \%$ in Pirin and $10 \%$ in Struma.

\section{DISCUSSION}

The ground beetles ( 52 species, 23 genera, and 12 tribes) collected during the study represent $7 \%$ of all Bulgarian carabid fauna species, $18 \%$ of all genera, and $33 \%$ of all tribes. The species-genus ratio was 1.85 in the first site, and 2.07 in the second. A very low species-genus ratio of ground beetles per site was also found in Cretan shrublands (Kaltsas et al. 2013). Similarly, most genera (with the exception of Harpalus) were represented by a very few species, indicative of an impoverished carabid fauna. Low species richness of carabids seems to be common for Mediterranean evergreen shrub and oak formations. In recent woodlands (less than 50 years old) at an altitude of about $700 \mathrm{~m}$ a.s.l., dominated by about $5 \mathrm{~m}$ high Quercus calliprinos Webb. trees, 21 species belonging to 12 genera were found (Timm et al. 2009). Thirty-two carabid species were captured in juniper maquis formations in five sampling sites in Greece (Kaltsas et al. 2012). In woodlands, mainly represented by Quercus pubescens Willd. and Q. coccifera L., with large open spaces covered by herbs and seedlings in southern Italy, 22 species of Carabidae were found (Elia et al. 2016). In organic and abandoned olive groves and maquis, 20 species from 16 genera were established (Solomou and Sfougaris 2016). Fifty-five species and 4,374 carabid individuals were collected from both grassland and forest habitats in "dehesa" ecosystems (Taboada et al. 2006). In Quercus pyrenaica Willd. forests, 381 individuals of 29 carabid species were collected (Taboada et al. 2004). Twenty-six genera (7.6 \pm 2.5 per site) and 42 Carabidae species $(8.2 \pm 3$ per site) were identified for 40 sites located within areas with natural phryganic, maquis or subalpine shrub vegetation (Kaltsas et al. 2013).

Furthermore, vast and very intensive land utilization has led to the degradation and disappearance of the natural evergreen oak woodlands in many regions (Grove and Rackham 2003). The small number of carabid species might also be resulting from all negative anthropogenic activities conducted in those habitats in the past as well as those persisting during more recent periods. On the other hand, we did establish some new species $(29 \%$ of all found species) where knowledge about beetles in those types of habitats is scarce. To draw more generalised conclusions, more localities will have to be examined systematically and more contemporary data must be obtained.

Some of the dominant species identified during the 
present study have been found to be abundant in different studies of Mediterranean maquis and maquislike habitats. Acinopus picipes, Calathus fuscipes, and Carabus coriaceus were common in maquises in Greece (Kaltsas et al. 2012, 2013). Calathus cinctus and Carabus coriaceus were the most abundant species five years after wildfire (Elia et al. 2016). In traditionally managed "dehesa" ecosystems in NW Spain, the most abundant species were generalist species Calathus fuscipes (24.5\% of the total catch) and Harpalus distinguendus (14\%) (Taboada et al. 2006). Calathus fuscipes was a dominant species in Quercus pyrenaica Willd. forests in NW Spain (Festuco heterophyllae-Querceto pyrenaicae sigmetum in the Mediterranean Region) (Taboada et al. 2004). Among the carabid species characterizing olive (Olea europaea L.) plantations that have replaced Quercus virgiliana (Ten.) forests and Mediterranean evergreens in southernmost regions of Italy, Amara aenea, Calathus cinctus, Calathus fuscipes, Harpalus attenuatus, Harpalus smaragdinus, Ophonus azureus, Pseudophonus rufipes, and Scybalicus oblongiusculus were recorded (Pizzolotto et al. 2018).

New upper altitude boundaries were established for the distribution of two species, but it would be tenuous to claim these new findings are evidence for a real shift of the species distribution to higher altitude. This is probably more reflective of lesser knowledge about the ecology of these species and their distribution in Bulgaria.

Zoogeographical analysis showed a predominance of the European-Asiatic and Mediterranean species in the established carabid fauna, which is in accordance with a more thermophilous and xerophilous biota. The predominance of the Mediterranean species is common for habitats near the Bulgarian Black Sea coast (Popov and Krusteva 1999; Teofilova et al. 2015) and the Eastern Rhodope Mountains (Teofilova and Kodzhabashev 2020). The specific geographic position and climatic conditions are a precondition for development of the respective vegetation (more xerothermic in this case), habitat types and zoocoenoses. These conditions reflect the xerothermophilic nature determined by the relict origin of the pseudomaquises formed under ancient Mediterranean events and favoured by the conditions in the steppe and steppe-like habitats in Asia. These gave rise to the present state of the carabids and the fauna in general.

As to the life forms of carabids, zoophagous life form groups are normally more numerous (Sharova 1981). A small number of life forms (14 of all 29 designated groups) was found to typify the steppe and semi-desert zones of Eurasia (Sharova 1981). The established proportions between the life form classes are also most similar to those in steppe and semi-desert zones of Eurasia (Sharova 1981). Such a small share of zoophages is unusual for other explored regions in Bulgaria (e.g.
Kodzhabashev and Penev 2006; Teofilova 2017, 2018a, 2019a) and reveals a unique combination of environmental factors in the Transitional-Mediterranean part of the country which has been studied. Relatively close proportions were established in the Eastern Rhodopes (Teofilova and Kodzhabashev 2020) and in scree habitats in Bulgaria (Teofilova 2019b) characterized by a similar xerothermic environment.

It seems that fossorial mixophytophagous harpaloid geohortobionts are the dominating life form not only in this study but also in many other regions of Bulgaria (e.g. Kodzhabashev and Penev 2006; Teofilova 2017, 2018a, b, 2019a, b; Teofilova and Kodzhabashev 2020). They were also the most abundant life form group in overgrazed sites in Greece (Kaltsas et al. 2012). Errant and large epigeobiont zoophages (Carabus spp.), which were the most numerous zoophages in Struma, were also dominant in undisturbed juniper maquis formations in Greece (Kaltsas et al. 2012).

The results of this work demonstrated the predominantly mesoxerophilous nature of pseudomaquis habitats, similar to that in the Eastern Rhodope Mountains (Teofilova and Kodzhabashev 2020) and contrasting with the predominantly mesophilous conditions in the western part of the Rhodope Mountains (Teofilova 2018a) and Vrachanska Planina Mountains (Teofilova 2019a), probably resulting from the typical forest-mountain conditions in the latter territories.

Although the habitats surveyed are similar to each other, the results of this study showed some differences with regard to their carabid fauna. This may be due both to gaps in the collection of material and to the presence of some specific environmental characteristics. One of the key factors is probably the influence of the mountainous climate at the first sampling site. The habitats that we studied occur only locally in Bulgaria and support specific carabid assemblages (not only ground beetles). Preserving these characteristic habitats is a keystone for the conservation of all target species living in this limited region and encompassed by the adjacent Natura 2000 zones.

\section{ACKNOWLEDGMENTS}

The sampling was supported by the National Science Fund via the Project No B-MU-1106/01. The author expresses gratitude to Dr Nikolay Kodzhabashev (University of Forestry, Sofia) for collaboration and to Dr Dragan Chobanov (IBER), Dr Mario Langourov (NMNH), Dr Nikolay Simov (NMNH), Dr Stoyan Lazarov (NMNH), Dr Stoyan Beshkov (NMNH) and Dr Kaloyan Ivanov (University of Cleveland) for providing the material. 


\section{REFERENCES}

Balaguer, E., F. Martinez-Ferri, M. E. Valladares, F. J. PerezCorona, F. J. Baquedano, F. J. Castillo, and E. Manrique. 2004. Population divergence in the plasticity of the response of Quercus coccifera to the light environment. Functional Ecology 15: 124-135.

di Castri, F., and V. Vitali-di Castri. 1981. Soil Fauna of Mediterranean-Climate Regions. In MediterraneanType Shrublands, Ecosystems Of The World, 445-478, edited by di Castri F., D. W. Goodall, and R. L. Specht. Amsterdam: Elsevier.

Elia, M., R. Lafortezza, E. Tarasco, and G. Sanesi. 2016. Response of beetle communities five years after wildfire in Mediterranean forest ecosystems. Redia XCIX: 107-116.

Grove, A. T., and O. Rackham. 2003. The Nature of Mediterranean Europe - an Ecological History. 384 pp. New Haven, CT, London: Yale University Press.

Gusev, C., D. Dimitrov, and R. Tzonev. 2015. Balkan Pseudomaquises. In Red Data Book of Republic of Bulgaria. Vol. 3. Natural Habitats, edited by Biserkov V. et al., 258-260. Sofia: BAS \& MOEW.

Kaltsas, D., A. Trichas, and M. Mylonas. 2012. Temporal organization patterns of epigean beetle communities (Coleoptera: Carabidae, Tenebrionidae) in different successional stages of eastern Mediterranean maquis. Journal of Natural History 46 (7-8): 495-515.

Kaltsas, D., A. Trichas, K. Kougioumoutzis, and M. Chatzaki. 2013. Ground beetles respond to grazing at assemblage level, rather than species-specifically: the case of Cretan shrublands. Journal of Insect Conservation 17: 681-697. DOI 10.1007/s10841-013-9553-0

Kodzhabashev, N. D., and L. D. Penev. 2006. The ground beetles (Coleoptera: Carabidae) of South Dobrudzha, Bulgaria. Acta Zoologica Bulgarica 58 (2): 147-180.

Kryzhanovskij, O. L. 1965. Composition and Origin of the Terrestrial Fauna of Middle Asia. Moscow-Leningrad: Nauka. 420 pp. (In Russian).

Kryzhanovskij, O. L. 1983. Fauna of the USSR. Coleoptera, Vol. 1, is. 2. The Ground-Beetles of Suborder Adephaga: Families Rhysodidae, Trachypachidae; Family Carabidae (Introduction, Overview of the Fauna of the USSR). Nauka: Leningrad. 341 pp. (In Russian).

Langourov, M., and N. Simov. 2006. Research on the biodiversity of model groups of animals in Kermes oak communities (Quercus coccifera L.). Historia Naturalis Bulgarica 17: 166 (In Bulgarian).

Langourov, M., A. Ignatov, and T. Baltadzhiev. 2008. A new locality of Kermes oak (Quercus coccifera L.) in Bulgaria. Historia Naturalis Bulgarica 20: 139-142 (In Bulgarian, English Summary).

Lazarov, S. P. 2005. Spiders (Araneae) from maquises in South-West Bulgaria - Part I. Acta Zoologica Bulgarica 57 (2): 145-152.
Lazarov, S. P. 2009. Spiders (Araneae) from maquis forests in SW Bulgaria - Part II. Acta Zoologica Bulgarica 61 (1): 33-37.

Pizzolotto, R., A. Mazzei, T. Bonacci, S. Scalercio, N. Iannotta, and P. Brandmayr. 2018. Ground beetles in Mediterranean olive agroecosystems: Their significance and functional role as bioindicators (Coleoptera, Carabidae). PLoS One 13 (3): e 0194551.

Popov, M. G. 1927. The main features of the historical development of the flora of Middle Asia. Bulletin of Middle Asian State University 15: 239-292 (In Russian).

Popov, V. V., and I. A. Krusteva. 1999. Epigeobiont animal assemblages from two landscapes of the Bulgarian Black Sea Coast: relationship to environmental gradients, assemblage structure and biodiversity. Part I: Ground beetles. Acta Zoologica Bulgarica 51 (1): 81-114.

Sharova, I. 1981. Life Forms of Carabids. Nauka: Moscow. 360 pp. (In Russian).

Solomou, A. D., and A. I. Sfougaris. 2016. Determining indicators of terrestrial biodiversity in olive grove and natural Mediterranean ecosystems. IJTRD 3 (1): 292-299.

Taboada, A., D. J. Kotze, and J. M. Salgado. 2004. Carabid beetle occurrence at the edges of oak and beech forests in NW Spain. European Journal of Entomology 101: 555-563.

Taboada, A., D. J. Kotze, J. M. Salgado, and R. Tarrega. 2006. The influence of habitat type on the distribution of carabid beetles in traditionally managed "dehesa" ecosystems in NW Spain. Entomologica Fennica 17: 284-295.

Teofilova, T. 2017. Ground beetles (Coleoptera: Carabidae) and some other invertebrates from the managed nature reserves "Dolna Topchiya" and "Balabana" (Lower valley of the river of Tundzha, Bulgaria). Ecologia Balkanica 9 (1): 63-77.

Teofilova, T. M. 2018a. A contribution to the study of ground beetles (Coleoptera: Carabidae) in the Western Rhodope Mts. (Bulgaria). Journal of BioScience and Biotechnology (2017) 6 (3): 203-209.

Teofilova, T. 2018b. Ground beetles (Coleoptera: Carabidae) in grasslands. Model for assessment of species diversity and ecosystem condition in Bulgaria. North-Western Journal of Zoology (2017) 14 (1): 1-12.

Teofilova, T. M. 2019a. Ground Beetles (Coleoptera: Carabidae) from the Region of Vrachanska Planina Mts. In Faunistic Diversity of Vrachanski Balkan Nature Park. Part 2. ZooNotes, Supplement 7, edited by Bechev D., and D. Georgiev, 39-58. Plovdiv University Press.

Teofilova, T. M. 2019b. Ground beetles (Coleoptera: Carabidae) from sparsely vegetated lands in Bulgaria. NorthWestern Journal of Zoology (2018) 15 (1): 30-41.

Teofilova, T. M., and N. D. Kodzhabashev. 2020. Ecological, faunistic and zoogeographical notes on the ground bee- 
tles (Coleoptera: Carabidae) from the Eastern Rhodope Mts. of Bulgaria. Forestry Ideas 26 (1) [59]: 77-96.

Teofilova, T., E. Markova, and N. Kodzhabashev. 2015. Ground beetles (Coleoptera: Carabidae) from the region of Cape Emine (Central Bulgarian Black sea coast). Part I. Taxonomic and zoogeographic structure, life forms, habitat and humidity preferences. ZooNotes 68: 1-18.

Timm, A., T. Dayan, T. Levanony, D. W. Wrase, and T. Assmann. 2008. Towards Combined Methods for Recording Ground Beetles: Pitfall Traps, Hand Picking and Sifting in Mediterranean Habitats of Israel. In Back to the Roots and Back to the Future? Towards a New Synthesis Amongst
Taxonomic, Ecological and Biogeographical Approaches in Carabidology, edited by Penev L., T. Erwin, and T. Assmann, 397-408. Sofia-Moscow: Pensoft.

Timm, A., J. Buse, T. Dayan, W. Hardtle, T. Levanony, and T. Assmann. 2009. At the interface of historical and present day ecology: Ground beetles (Coleoptera: Carabidae) in woodlands and open habitats in Upper Galilee (Israel). Zoology in the Middle East 47: 93-104.

Tsiourlis, G., P. Konstantinidis, and P. Xofis. 2009. Syntaxonomy and synecology of Quercus coccifera Mediterranean shrublands in Greece. Journal of Plant Biology 52: 433-447. DOI 10.1007/s12374-009-9056-4 